\title{
Lactoferrin and transferrin damage of the Gram-negative outer membrane is modulated by $\mathrm{Ca}^{2+}$ and $\mathrm{Mg}^{2+}$
}

\author{
Richard T. Ellison, III, ${ }^{*}$ F. Marc LaForce, ${ }^{1 \dagger}$ Theodore J. Giehl, ${ }^{1}$ Dorothy S. Boose ${ }^{1}$ \\ and BRUCE E. DUNN $\ddagger$ \\ ${ }^{1}$ Medical and ${ }^{2}$ Pathology Services, Department of Veterans Affairs Medical Center and the Division of Infectious \\ Diseases, Department of Medicine, University of Colorado School of Medicine, Denver, CO 80220, USA
}

(Received 30 August 1989; revised 6 February 1990; accepted 14 February 1990)

\begin{abstract}
Lactoferrin and transferrin have antimicrobial activity against selected Gram-negative bacteria, but the mechanism of action has not been defined. We studied the ability of lactoferrin and transferrin to damage the Gram-negative outer membrane. Lipopolysaccharide release by the proteins could be blocked by concurrent addition of $\mathrm{Ca}^{2+}$ and $\mathrm{Mg}^{2+}$. Addition of $\mathrm{Ca}^{2+}$ also blocked the ability of lactoferrin to increase the susceptibility of Escherichia coli to rifampicin. Transferrin, but not lactoferrin, increased susceptibility of Gram-negative bacteria to deoxycholate, with reversal of sensitivity occurring with exposure to $\mathrm{Ca}^{2+}$ or $\mathrm{Mg}^{2+}$. In transmission electron microscopy studies polymyxin B caused finger-like membrane projections, but no morphological alterations were seen in cells exposed to EDTA, lactoferrin or transferrin. These data provide further evidence that lactoferrin and transferrin act as membrane-active agents with the effects modulated by $\mathrm{Ca}^{2+}$ and $\mathrm{Mg}^{2+}$.
\end{abstract}

\section{Introduction}

Lactoferrin and transferrin are iron-binding proteins found in essentially all human secretions. The highest level of transferrin is in serum, and that of lactoferrin within polymorphonuclear leucocytes and in mucosal fluids (Masson et al., 1966, 1969). They have protean effects on micro-organisms; variably acting as growth factors, inducing iron uptake systems, and for selected bacteria producing bacteriostasis (Bullen, 1981; Bullen et al., 1978; Griffiths, 1975; Norrod \& Williams, 1978). It has been suggested that this last effect contributes to antibacterial host defence, and that the mechanism of bacteriostasis is sequestration of environmental iron causing nutritional deprivation of susceptible organisms (Finkelstein et al., 1983).

However, a variety of studies have indicated additional antimicrobial effects of the proteins not readily explainable by this hypothesis. The antimicrobial activity of lactoferrin for Gram-negative organisms can be increased by addition of immunoglobulins (BoesmanFinkelstein \& Finkelstein, 1985; Rainard, 1986; Spik et al., 1976; Stephens et al., 1980). While this could be due

$\dagger$ Present address: Department of Medicine, Genesee Hospital, Rochester, NY 14607, USA.

$\ddagger$ Present address: Pathology Service, Department of Veterans Affairs Medical Center, Little Rock, Arkansas, USA. to further iron deprivation through anti-siderophore antibodies, enhancing antibodies have been found to be directed against lipopolysaccharide (LPS) O-antigens (Finkelstein et al., 1983; Stephens et al., 1980). Similarly, transferrin contributes to antibody- and complementmediated serum antibacterial activity towards several Gram-negative species, although the mechanism of action is not known (Bullen et al., 1978; Griffiths, 1975; Norrod \& Williams, 1978; Fitzgerald \& Rogers, 1980). Finally, other work indicates that lactoferrin may directly kill selected bacterial strains through an undefined mechanism (Arnold et al., 1977, 1982; Bortner et al., 1986; Kalmar \& Arnold, 1988).

Recent work now suggests that lactoferrin and transferrin can directly damage the outer membrane of Gram-negative bacteria in a manner similar to the synthetic chelator EDTA (Ellison et al., 1988). Gramnegative bacteria have an outer membrane composed of an asymmetric lipid bilayer with large LPS molecules restricted to the outer leaflet (Leive, 1974; Nikaido \& Vaara, 1985). The LPS molecules are anionic and are stabilized within the membrane by associated cations, primarily $\mathrm{Ca}^{2+}$ and $\mathrm{Mg}^{2+}$ (Coughlin et al., 1983). By binding membrane-stabilizing cations, EDTA releases LPS from the outer membrane, concurrently increasing membrane permeability to hydrophobic molecules and sensitizing bacteria to membrane-active agents (Leive, 
1974; Nikaido \& Vaara, 1985). As the transferrin proteins can bind numerous metal ions in addition to iron (Bullen et al., 1978), it was theorized that lactoferrin and transferrin could have effects on the Gram-negative outer membrane comparable to EDTA. Lactoferrin, and to a lesser extent, transferrin, were shown to release LPS from Gram-negative bacteria at physiological concentrations and $\mathrm{pH}$ (Ellison et al., 1988). Moreover, the proteins also sensitized bacteria to the hydrophobic antibiotic rifampicin (Ellison et al., 1988). To further define the mechanism of membrane damage by these iron-binding proteins, the impact of the membranestabilizing cations $\mathrm{Ca}^{2+}$ and $\mathrm{Mg}^{2+}$ on their effects has now been studied.

\section{Methods}

Lactoferrin and transferrin. Human lactoferrin purified from milk was purchased commercially (Sigma or Calbiochem) as was human transferrin purified from serum (Sigma). It was known that the lactoferrin from one of the commercial sources had not been exposed to any known chelators during its purification (personal communication, Calbiochem).

Analytical procedures. Protein concentrations were determined by the biuret method of Mokrasch \& McGilvery (1956). The levels of calcium, magnesium or iron in individual samples were measured using flameless atomic absorption spectrophotometry (Perkin-Elmer 5000 spectrophotometer equipped with a model 500 programmer and an AS1 auto sampler) in the laboratory of Dr A. Alfrey (Department of Veterans Affairs Medical Center, Denver, CO, USA).

Bacteria and culture conditions. UDP-galactose epimerase deficient strains E. coli CL99-2 and Salmonella montevideo SL5222 were obtained from Dr K. A. Joiner (National Institutes of Health, Bethesda, MD, USA). E. coli CL99-2 is a 'smooth', O111 serotype, serum-resistant strain that incorporates galactose into the $O$-polysaccharide repeating LPS subunits but is incapable of synthesizing galactose. Unless provided with exogenous galactose, this organism cannot produce a complete LPS molecule (Joiner et al., 1984). When the strain is grown in the presence of $\left[{ }^{3} \mathrm{H}\right]$ galactose, the radiolabel is almost exclusively incorporated into the LPS O-polysaccharide (Goldman \& Leive, 1980). $S$. montevideo SL5222 lacks both UDP-galactose epimerase and phosphomannose isomerase, both of which affect LPS biosynthesis (Joiner et al., 1986). Only cells grown in the presence of both mannose and galactose can synthesize a complete LPS structure. Galactose is incorporated solely in the core oligosaccharide while four mannose residues are incorporated into each $\mathrm{O}$-antigen subunit. In the present studies, $E$. coli CL99-2 was grown in a defined galactose-deficient medium (modified WMS broth) as described previously (Ellison et al., 1988), and S. montevideo SL5222 was grown in Luria broth. For selected experiments the media were supplemented with defined concentrations of $\mathrm{MgCl}_{2}, \mathrm{CaCl}_{2}$ or ferric chloride.

A wild-type 'smooth' Salmonella typhimurium strain, SL696, that also incorporates a large percentage of exogenous galactose into LPS was obtained from Dr I. M. Helander (National Public Health Institute, Helsinki, Finland) (Hukari et al., 1986). This strain was initially grown in Luria broth supplemented with $2 \mathrm{~mm}-\mathrm{CaCl}_{2}$ before testing for sensitivity to lactoferrin or transferrin-mediated LPS release (Hukari $e t$ $a l ., 1986)$. For selected experiments the medium was supplemented with defined concentrations of $\mathrm{MgCl}_{2}, \mathrm{CaCl}_{2}$ or ferric chloride.
E. coli 11744 has a non-encapsulated 'smooth' LPS phenotype and is a human blood isolate from the University of Colorado, Health Sciences Center Clinical Microbiology Laboratory blood culture collection. Clinical isolates of $E$. coli (including a serotype $\mathrm{O} 26$ strain), Serratia marcescens, Enterobacter cloacae, Proteus mirabilis and Pseudomonas aeruginosa were obtained from $\mathrm{Dr}$ W.-L. Wang, Denver Department of Veterans Affairs, Medical Center Clinical Microbiology Laboratory.

LPS release assay. Release of LPS from bacteria was determined using the assay described previously (Ellison et al., 1988). Briefly, the strain to be tested was grown for $4 \mathrm{~h}$ at $37^{\circ} \mathrm{C}$ in $1 \mathrm{ml}$ of defined medium supplemented with $0.1 \mathrm{mM}$ unlabelled galactose and $4-15 \mu \mathrm{Ci} \mathrm{D}-[6-$ ${ }^{3} \mathrm{H}$ ]galactose. The cells were then centrifuged, washed and suspended in Hanks' balanced salt solution lacking calcium and magnesium (HBSS-CM) (Sigma). Duplicate $1.0 \mathrm{ml}$ release assays were prepared containing approximately $5 \times 10^{7}$ c.f.u. $\left[{ }^{3} \mathrm{H}\right]$ galactose-labelled bacteria, buffer and varying concentrations of test materials in polypropylene tubes. The $\mathrm{pH}$ was maintained between 7 and 7.5. After addition of bacteria, 0 min samples were immediately agitated, centrifuged and the supernatant and pellet fractions counted for $5 \mathrm{~min}$ for $\beta$-emissions with appropriate corrections for background counts. The $30 \mathrm{~min}$ assays were incubated at $37^{\circ} \mathrm{C}$ and then similarly agitated, centrifuged and counted.

The percentage of radiolabel released at $30 \mathrm{~min}$ was determined as follows.

Percentage release $=[30 \mathrm{~min}$ sample supernatant c.p.m. $/(30 \mathrm{~min}$ sample supernatant c.p.m. +30 min sample pellet c.p.m. $) \times 100]-[0$ min buffer supernatant c.p.m./(0 min supernatant c.p.m. $+0 \mathrm{~min}$ pellet c.p.m.) $\times 100]$

For studies of the ability of calcium, iron or magnesium to block LPS release, each experiment compared a series of samples incubated in HBSS-CM with samples incubated with a selected single supplemental concentration of $\mathrm{CaCl}_{2}$, ferric chloride or $\mathrm{MgCl}_{2}$. For example, for $3 \mathrm{~d}$ parallel LPS release assays were done with lactoferrin and transferrin in HBSS-CM and in HBSS-CM supplemented with $1.3 \times 10^{-3} \mathrm{M}^{-\mathrm{Ca}^{2+}}$. The $\mathrm{Ca}^{2+}$ concentrations were chosen to represent $0,6 \cdot 25,12,25,50$ and $100 \%$ of the calcium in HBSS, and the $\mathrm{Mg}^{2+}$ concentrations to represent 0,50 , and $100 \%$ of the magnesium in HBSS. The iron concentrations were chosen to provide approximately $100 \%$ and $200 \%$ of the iron necessary to saturate lactoferrin and transferrin.

To further exclude potential artifacts from unrecognized contaminants, release assays were also done using lactoferrin that was dialysed for $20 \mathrm{~h}$ against $\mathbf{0 \cdot 1} \mathrm{M}$-sodium perchlorate (Sigma) to dissociate any unrecognized contaminating anions, and then equilibrated with HBSSCM.

Effect of lactoferrin and transferrin on bacterial susceptibility to rifampicin. E. coli strain 11744 was grown to a density of $10^{8}$ c.f.u. $\mathrm{ml}^{-1}$ in modified WMS broth with $0.03 \mathrm{mM}$-galactose. An inoculum of $5 \times$ $10^{5}$ c.f.u. was added to $1 \mathrm{ml}$ of WMS broth with or without EDTA, lactoferrin, rifampicin or supplemental calcium. Time-kill curves were developed by incubating the mixtures at $37^{\circ} \mathrm{C}$ and removing samples at 0,2 and $4 \mathrm{~h}$. Bacterial colony counts were measured by plating overnight at $37^{\circ} \mathrm{C}$ on tryptic soy agar (TSA, Sigma).

Effect of lactoferrin and transferrin on bacterial susceptibility to deoxycholate. The E. coli serotype $\mathrm{O} 26$ strain was grown in tryptic soy broth, harvested in stationary or early exponential phase of growth, and washed twice in saline $(0.9 \% \mathrm{NaCl}) .10^{5}$ c.f.u. inoculum was suspended in $0.9 \%$ saline with or without varying concentrations of lactoferrin and transferrin for $30 \mathrm{~min}$ at $37^{\circ} \mathrm{C}$. Samples were removed at 0 and $30 \mathrm{~min}$ and bacterial colony counts determined by initially plating overnight at $37^{\circ} \mathrm{C}$ on blood agar, MacConkey agar, TSA, and TSA with $0.085 \%$ ( $w / v)$ sodium deoxycholate. Studies of the individual constituents of MacConkey agar used $0.085 \%$ sodium deoxycholate, $0.085 \%$ (w/v) 
cholate, $0.003 \%(w / v)$ neutral red (Baker) and $0.0001 \%(w / v)$ crystal violet (Matheson, Coleman \& Bell). Subsequent experiments were plated only on agar containing deoxycholate (MacConkey or TSA with deoxycholate). Activity was defined by the decrease in c.f.u. remaining at $30 \mathrm{~min}$. To determine the effect of $\mathrm{pH}$, studies were repeated in $0.001 \mathrm{M}$-barbital acetate buffer at $\mathrm{pH} 6.5,7.2$ or 8.2 .

To determine if transferrin-mediated deoxycholate susceptibility could be reversed, a $10^{5}$ c.f.u. inoculum of $E$. coli cells was first incubated with $1 \mathrm{mg}$ transferrin in $1.0 \mathrm{ml} 0.9 \%$ saline for $30 \mathrm{~min}$ at $37^{\circ} \mathrm{C}$. A $0.1 \mathrm{ml}$ sample was then removed and added to $9.9 \mathrm{ml}$ of varying solutions at $37^{\circ} \mathrm{C}$ (water, HBSS, $0.9 \%$ saline, $10^{-4} \mathrm{M}^{-\mathrm{CaCl}_{2}}$, $10^{-4} \mathrm{M}_{-} \mathrm{MgSO}_{4}, 10^{-5} \mathrm{M}$-ferric chloride, $10^{-4} \mathrm{M}-\mathrm{Na}_{2} \mathrm{HPO}_{4}, 10^{-4} \mathrm{M}-$ $\mathrm{CaCl}_{2} / 10^{-4} \mathrm{M}-\mathrm{Na}_{2} \mathrm{HPO}_{4}$ and $10^{-4} \mathrm{M}-\mathrm{MgSO}_{4} / 10^{-4} \mathrm{M}-\mathrm{Na}_{2} \mathrm{HPO}_{4}$ ). Samples were removed immediately after dilution, and 15 and 30 min later. Bacterial colony counts were determined by plating overnight at $37^{\circ} \mathrm{C}$ on deoxycholate containing agar. The studies with $0.9 \%$ saline were repeated at $4{ }^{\circ} \mathrm{C}$ and $37^{\circ} \mathrm{C}$.

Transmission electron microscopy. E. coli CL99-2 and S. typhimurium SL696 cells were treated as in the LPS release experiments. Cells were grown for $4 \mathrm{~h}$ (mid-exponential phase of growth) at $37^{\circ} \mathrm{C}$, centrifuged, washed and diluted. Release assays $(1.0 \mathrm{ml})$ were prepared incorporating $10^{9}$ c.f.u. $\mathrm{ml}^{-1}$ in HBSS-CM in buffer alone or in the presence of $2 \times 10^{-5} \mathrm{M}$-EDTA, $2 \times 10^{-5} \mathrm{M}$-transferrin, $2 \times 10^{-5} \mathrm{M}$-lactoferrin or $30 \mu \mathrm{g}$ polymyxin $\mathrm{B} \mathrm{ml}^{-1}$. Samples were incubated at $37^{\circ} \mathrm{C}$ for $30 \mathrm{~min}$, agitated and centrifuged. The bacterial pellet was resuspended in $2 \%$

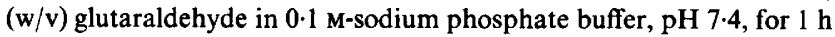
at $4{ }^{\circ} \mathrm{C}$. Samples were postfixed in buffered $1 \%(\mathrm{w} / \mathrm{v})$ osmium tetroxide, dehydrated through a graded series of ethanols, and embedded in Poly/bed 812-araldite (Mollenhauer medium, Polysciences). For electron microscopy, $70 \mathrm{~nm}$ thin sections were obtained with diamond knives and stained routinely with aqueous solutions of uranyl acetate and lead citrate. Sections were examined with a Philips CM-12 transmission electron microscope at $60 \mathrm{kV}$.
Statistical analysis. Data analysis was done by independent and paired Student's $t$-tests using the ABSTAT software package (AndersonBell, Canon City, CO, USA).

\section{Results}

\section{LPS release}

To define the effects of calcium, iron and magnesium on LPS release due to lactoferrin and transferrin, the effects of the proteins on $E$. coli CL99-2 and $S$. typhimurium SL696 were studied in the presence of graded concentrations of the cations. As expected from previous studies, the degree of LPS release differed slightly between the strains but the results were otherwise similar; only the $S$. typhimurium SL696 data are shown (Table 1). Supplemental iron was able to inhibit LPS release by both of the proteins, with less effect on the activity of EDTA. Release of LPS mediated by lactoferrin and transferrin was similar when studied in HBSS-CM or in HBSS-CM with the addition of $8 \times 10^{-5} \mathrm{M}-\mathrm{Ca}^{2+}$. Comparable to previous work, lactoferrin consistently released more ${ }^{3} \mathrm{H}$ labelled LPS than transferrin. As the $\mathrm{Ca}^{2+}$ concentration was increased there was graded and parallel inhibition of LPS release due to each of the proteins as well as EDTA. Of note, however, $2 \times 10^{-5} \mathrm{M}$-lactoferrin caused significant LPS release from both bacterial strains in the presence of $1.6 \times 10^{-4} \mathrm{M}-\mathrm{Ca}^{2+}$, and $2 \times 10^{-5} \mathrm{M}-$

Table 1. Effect of increasing $\mathrm{Ca}^{2+}$ or $\mathrm{Mg}^{2+}$ concentration on lactoferrin- and transferrinmediated release of ${ }^{3} \mathrm{H}$-labelled LPS from S. typhimurium SL696

The release of ${ }^{3} \mathrm{H}$-labelled LPS was determined as described in Methods. Results are means + SEM of three experiments. Each concentration of supplemental $\mathrm{Ca}^{2+}, \mathrm{Fe}^{3+}$ or $\mathrm{Mg}^{2+}$ was studied at least in triplicate with a simultaneous unsupplemented control : the respective unsupplemented $\mathrm{Ca}^{2+}, \mathrm{Fe}^{3+}$ and $\mathrm{Mg}^{2+}$ control results represent 16,6 and 6 assays respectively. The significance of results (versus LPS release in buffer alone) is indicated as follows (all statistics by paired $t$-test): $(a) P<0 \cdot 05$; (b) $P<0 \cdot 01$; (c) $P<0.005$; (d) $P \leqslant 0.0001$.

\begin{tabular}{|c|c|c|c|c|c|}
\hline \multirow[b]{2}{*}{$\begin{array}{l}\text { Assay } \\
\text { buffer } \\
\text { supplement }\end{array}$} & \multirow[b]{2}{*}{$\begin{array}{l}\text { Assay } \\
\text { buffer ... }\end{array}$} & \multicolumn{4}{|c|}{ LPS release } \\
\hline & & $\begin{array}{c}\text { HBSS-CM } \\
\text { buffer }\end{array}$ & $\begin{array}{c}\text { HBSS-CM } \\
+ \text { EDTA } \\
\left(2 \times 10^{-5} \mathrm{M}\right)\end{array}$ & $\begin{array}{c}\text { HBSS-CM } \\
+ \text { lactoferrin } \\
\left(2 \mathrm{mg} \mathrm{ml}^{-1}\right)^{*}\end{array}$ & $\begin{array}{c}\text { HBSS-CM } \\
+ \text { transferrin } \\
\left(2 \mathrm{mg} \mathrm{ml}^{-1}\right)^{*}\end{array}$ \\
\hline Unsupplemented & & $7 \cdot 3 \pm 1$ & $16 \cdot 3 \pm 1^{d}$ & $18 \cdot 6 \pm 2^{d}$ & $8 \cdot 8 \pm 1^{a}$ \\
\hline $\mathrm{Ca}^{2+8} \times 10^{-5} \mathrm{M}$ & & $6 \cdot 1 \pm 1$ & $14.9 \pm 1^{d}$ & $13 \cdot 4 \pm 1^{d}$ & $9 \cdot 6 \pm 1^{a}$ \\
\hline $1.6 \times 10^{-4} \mathrm{M}$ & & $6 \cdot 1 \pm 1$ & $10 \cdot 5 \pm 1^{b}$ & $10 \cdot 8 \pm 1^{c}$ & $7 \cdot 3 \pm 1$ \\
\hline $3.3 \times 10^{-4} \mathrm{M}$ & & $3 \cdot 0 \pm 1$ & $6 \cdot 2 \pm 2$ & $7 \cdot 0 \pm 3$ & $4 \cdot 4 \pm 2$ \\
\hline $6.5 \times 10^{-4} \mathrm{M}$ & & $5 \cdot 2 \pm 1$ & $7 \cdot 5 \pm 1$ & $8 \cdot 1 \pm 1$ & $5 \cdot 0 \pm 0.3$ \\
\hline $1.3 \times 10^{-3} \mathrm{M}$ & & $2 \cdot 2 \pm 0 \cdot 2$ & $2 \cdot 1 \pm 0 \cdot 2$ & $3.1 \pm 0.5$ & $1.5 \pm 0.2$ \\
\hline Unsupplemented $\dagger$ & & $2 \cdot 7 \pm 1$ & $17 \cdot 8 \pm 1^{d}$ & $15 \cdot 7 \pm 1^{d}$ & $8 \cdot 1 \pm 2^{b}$ \\
\hline $\mathrm{Fe}^{3+} 4 \times 10^{-5} \mathrm{M}$ & & $2 \cdot 7 \pm 1$ & $13 \cdot 1 \pm 2^{a}$ & $9 \cdot 1 \pm 1^{c}$ & $3 \cdot 6 \pm 1$ \\
\hline $8 \times 10^{-5} \mathrm{M}$ & & $2 \cdot 6 \pm 2$ & $13 \cdot 1 \pm 2^{a}$ & $7 \cdot 4 \pm 2$ & $3 \cdot 4 \pm 1$ \\
\hline Unsupplemented & & $10 \cdot 3 \pm 3$ & $19 \cdot 6 \pm 2^{d}$ & $23 \cdot 3 \pm 5^{c}$ & $10 \cdot 9 \pm 2$ \\
\hline $\mathrm{Mg}^{2+4} \times 10^{-4} \mathrm{M}$ & & $3.8 \pm 2$ & $6 \cdot 5 \pm 3$ & $1 \cdot 4 \pm 2$ & $0 \cdot 1 \pm 3$ \\
\hline $8 \times 10^{-4} \mathrm{M}$ & & $5 \cdot 7 \pm 2$ & $9 \cdot 3 \pm 2^{c}$ & $4 \cdot 7 \pm 1$ & $4 \cdot 1 \pm 1$ \\
\hline
\end{tabular}

* Molar concentration about $2 \times 10^{-5}$.

$\dagger<4 \times 10^{-8}$ M-iron. 


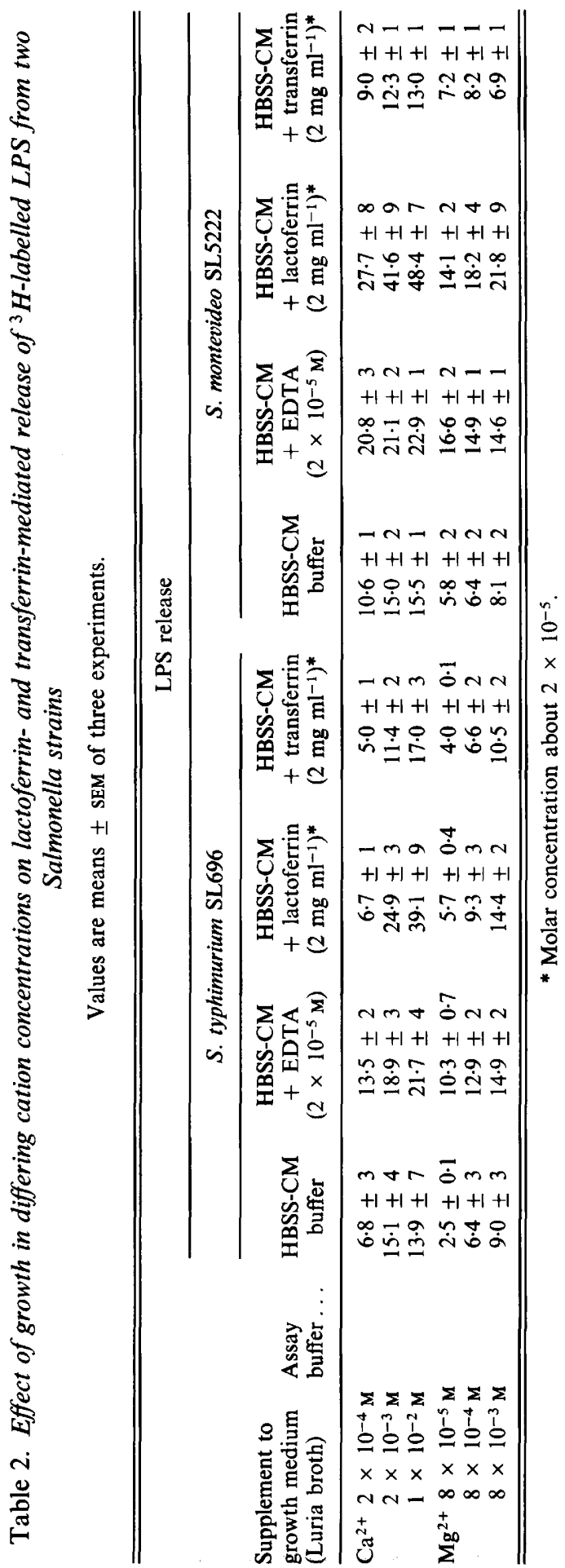


transferrin caused LPS release from only the $E$. coli strain at this same $\mathrm{Ca}^{2+}$ concentration. Supplemental $\mathrm{Mg}^{2+}$ also produced a graded inhibition of LPS release by both proteins from both bacterial strains. Thus, these studies confirm the importance of $\mathrm{Ca}^{2+}$ and $\mathrm{Mg}^{2+}$ to the membrane effects of lactoferrin and transferrin, and also indicate that LPS release due to the proteins can occur in the presence of $\mathrm{Ca}^{2+}$ concentrations that exceed the protein concentration.

Previous work by other investigators has indicated that growing bacteria in the presence of increasing concentrations of $\mathrm{Ca}^{2+}$ or $\mathrm{Mg}^{2+}$ increases the percentage of LPS released by EDTA, presumably because more cations are incorporated into the outer membrane (Leive, 1974). To further define the mechanism of lactoferrin and transferrin, the effect of media cation concentration on LPS release by these proteins was comparably evaluated. As preliminary studies showed that lactoferrin-mediated LPS release from $S$. montevideo SL5222 was of a greater magnitude than that from E. coli CL99-2 (data not shown), this strain and S. typhimurium SL696 were used. For both strains, the amount of LPS released from the bacterial membrane increased as the concentration of $\mathrm{Ca}^{2+}$ or $\mathrm{Mg}^{2+}$ in the growth medium increased (Table 2). However, the increase in LPS release was substantially greater for EDTA and lactoferrin than for transferrin or buffer alone. Growing bacteria in the presence of supplemental iron did not influence LPS release (data not shown). These results are again consistent with the concept that $\mathrm{Ca}^{2+}$ and $\mathrm{Mg}^{2+}$ are important to the stability of the Gram-negative outer membrane, and that as their concentration within the membrane increases, the membrane becomes more susceptible to damage.

Additional studies also found that lactoferrin-mediated LPS release from $S$. typhimurium SL696 and $S$. montevideo SL5222 was not influenced by pretreatment of lactoferrin with sodium perchlorate indicating that the LPS release was not being mediated by an unrecognized contaminating anion that had chelating activity (data not shown).

\section{Rifampicin susceptibility}

To determine whether the $\mathrm{Ca}^{2+}$ concentration might influence the previously defined interaction between the iron-binding proteins and rifampicin, time-kill studies were done on a wild type $E$. coli strain (Table 3 ). Addition of $\mathrm{Ca}^{2+}$ had no effect on the growth of the strain in media alone or in the presence of lactoferrin, transferrin or EDTA. However, it significantly decreased the ability of both lactoferrin and EDTA to sensitize this strain to rifampicin, a finding consistent with the observed effect of the cation on LPS release.
Table 3. Effect of $\mathrm{Ca}^{2+}$ on the ability of EDTA, lactoferrin and transferrin to enhance the susceptibility of a clinical

\section{E. coli strain to rifampicin}

Values are means \pm SEM of five experiments. The significance of results is indicated as follows (all statistics by paired $t$-test): (a) $P<0.005$ versus WMS; (b) $P<0.005$ versus rifampicin; (c) $P<0.01$ versus experiments without added $\mathrm{Ca}^{2+}$.

\begin{tabular}{llr}
\hline \hline \multirow{2}{*}{$\begin{array}{c}\text { Supplement to } \\
\text { growth medium } \\
\text { (modified WMS) }\end{array}$} & \multicolumn{2}{c}{$\begin{array}{c}\log _{10} \text { (Change in no. of bacteria } \\
\text { after } 4 \mathrm{~h})\end{array}$} \\
\cline { 2 - 3 } & $-\mathrm{Ca}^{2+}$ & $+1 \cdot 3 \mathrm{mM}-\mathrm{Ca}^{2+}$ \\
\hline None & $2 \cdot 0 \pm 0 \cdot 1$ & $2 \cdot 0 \pm 0 \cdot 1$ \\
EDTA $\left(2 \times 10^{-5} \mathrm{M}\right)$ & $1.9 \pm 0 \cdot 2$ & $2 \cdot 0 \pm 0 \cdot 1$ \\
Lactoferrin $\left(2 \mathrm{mg} \mathrm{ml}^{-1}\right)$ & $1 \cdot 4 \pm 0 \cdot 1^{a}$ & $1 \cdot 3 \pm 0 \cdot 1$ \\
Transferrin $\left(2 \mathrm{mg} \mathrm{ml}^{-1}\right)$ & $1 \cdot 0 \pm 0 \cdot 1^{a}$ & $1 \cdot 1 \pm 0 \cdot 1$ \\
Rifampicin $\left(5 \mu \mathrm{ml}^{-1}\right)$ & $1 \cdot 3 \pm 0 \cdot 1$ & $1 \cdot 8 \pm 0 \cdot 1$ \\
Rifampicin + EDTA & $0 \cdot 6 \pm 0 \cdot 2$ & $1 \cdot 7 \pm 0 \cdot 1^{c}$ \\
Rifampicin + lactoferrin & $0 \cdot 0 \pm 0 \cdot 2^{b}$ & $0 \cdot 7 \pm 0 \cdot 1^{c}$ \\
Rifampicin + transferrin & $0 \cdot 8 \pm 0 \cdot 1$ & $0 \cdot 8 \pm 0 \cdot 1$ \\
\hline \hline
\end{tabular}

\section{Deoxycholate studies}

EDTA and polycationic agents can sensitize Gramnegative bacteria to detergents, and previous studies have demonstrated that other host factors sensitize Gram-negative bacteria to deoxycholate (LaForce \& Boose, 1981; Leive, 1974). Thus, experiments were done to investigate whether the iron-binding proteins could sensitize bacteria to this detergent. Lactoferrin- and transferrin-treated serotype $\mathrm{O} 26 \mathrm{E}$. coli were plated on media with or without sodium deoxycholate. Although lactoferrin at concentrations from $0.5-2.0 \mathrm{mg} \mathrm{ml}^{-1}$ did not affect the bacteria, transferrin at concentrations from $0 \cdot 1-1 \cdot 0 \mathrm{mg} \mathrm{ml}^{-1}$ consistently sensitized this strain to sodium deoxycholate. After a $30 \mathrm{~min}$ incubation with $1.0 \mathrm{mg}$ transferrin $\mathrm{ml}^{-1}$, no effect on bacterial colony counts was observed when exposed cells were plated on blood agar or TSA alone. In contrast, a greater than $80 \%$ decrease in colony counts was seen when transferrintreated cells were plated on MacConkey agar or TSA with deoxycholate. By testing isolated components of MacConkey agar individually, it was further confirmed that the factor in the agar that transferrin sensitized bacteria to was deoxycholate; $98.9 \pm 0.8 \%$ killing occurred in the presence of deoxycholate and $<10 \%$ killing with exposure to crystal violet, neutral red or cholate (mean \pm SEM of three experiments). Transferrin sensitization of cells to deoxycholate was found to be dose dependent, but progressively decreased as the $\mathrm{pH}$ was raised from 6.6 to $8 \cdot 2$ (Fig. 1). In addition, saturation of transferrin with iron markedly decreased but did not completely eliminate the antibacterial activity (Fig. 2). 


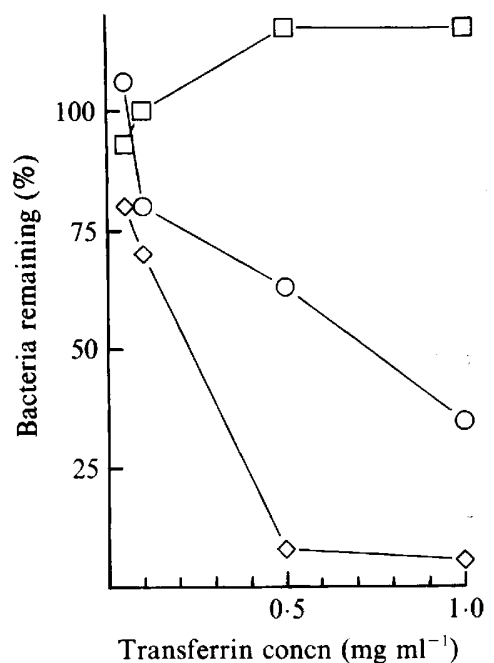

Fig. 1. Influence of $\mathrm{pH}$ and transferrin concentration on sensitization of $E$. coli $\mathrm{O} 26$ to deoxycholate (expressed as the percentage of initial bacterial inoculum remaining after $30 \mathrm{~min}$ incubation with transferrin and subsequent plating on media containing $0.085 \%$ sodium deoxycholate; mean of two experiments). $\square, \mathrm{pH} 8.2 ; \mathrm{O}, \mathrm{pH} 7 \cdot 2 ; \diamond, \mathrm{pH} 6.6$. Additional experiments with $1.0 \mathrm{mg}$ transferrin $\mathrm{ml}^{-1}$ demonstrated $8 \pm 4 \%$ (mean \pm SEM) bacteria remaining at $30 \mathrm{~min}$ at $\mathrm{pH} 6 \cdot 6,49 \pm$ $15 \%$ remaining at $\mathrm{pH} 7 \cdot 2$, and $111 \pm 3 \%$ remaining at $\mathrm{pH} 8.2(P<0.05$ for $\mathrm{pH} 6.6$ versus $\mathrm{pH} 7.2 ; P<0.01$ for $\mathrm{pH} 7.2$ versus $\mathrm{pH} 8.2 ; P<0.001$ for $\mathrm{pH} 6.6$ versus $\mathrm{pH} 8 \cdot 2$ ).

Two other clinical $E$. coli strains as well as single clinical strains of Serratia marcescens, Enterobacter cloacae and Pseudomonas aeruginosa were similarly sensitized to deoxycholate by transferrin. A clinical strain of Proteus mirabilis was resistant. Overall, these findings indicate that transferrin alters the Gram-negative outer membrane and thereby increases bacterial susceptibility to deoxycholate.

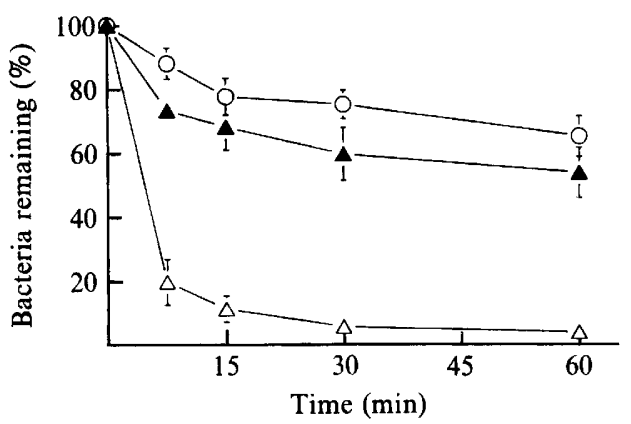

Fig. 2. Effect of incubating $E$. coli $\mathrm{O} 26$ for varying time intervals with saline $(O)$, apotransferrin $(\triangle)$ or iron-saturated transferrin $(A)$ on subsequent sensitization to deoxycholate (expressed as the percentage of initial bacterial inoculum remaining after incubation with transferrin and subsequent plating on media containing $0.085 \%$ sodium deoxycholate; mean \pm SEM of 10 experiments).

The outer membrane damage induced by EDTA can be reversed by incubating EDTA-treated cells in media containing a large excesss of $\mathrm{Ca}^{2+}$ or $\mathrm{Mg}^{2+}$ (Leive, 1974). Similar studies were done to evaluate whether transferrin-induced deoxycholate susceptibility could be reversed. This was tested by treating cells with transferrin, then diluting the transferrin concentration 100 -fold and holding the exposed cells in solutions containing iron, $\mathrm{Ca}^{2+}, \mathrm{Mg}^{2+}$ or phosphate. Reversal of membrane damage did occur to varying degrees in essentially all solutions, but the greatest bacterial recovery was seen when the cells were held in solutions containing both $\mathrm{Ca}^{2+}$ or $\mathrm{Mg}^{2+}$ and phosphate (Table 4). To determine if the recovery from transferrin damage was energy dependent further studies compared reversal at different incubation temperatures.

Table 4. Reversal of transferrin sensitization to deoxycholate by incubation of exposed E. coli cells in differing salt solutions

\begin{abstract}
Values represent the percentage of initial bacterial inoculum remaining after incubation with transferrin and subsequent plating on media containing $0.085 \%$ sodium deoxycholate. The 0 min results indicate the percentage of the initial bacterial inoculum that was present immediately after the $30 \mathrm{~min}$ incubation with $1 \mathrm{mg}$ transferrin $\mathrm{ml}^{-1}$. The $15 \mathrm{~min}$ and 30 min results indicate the percentage of the initial bacterial inoculum that was present after the bacterial cells were allowed additional time to recover in the respective solution. The values are means \pm SEM. Numbers in parentheses are $P$ values comparing the percentage of bacteria remaining at $0 \mathrm{~min}$ with the percentages at 15 and $30 \mathrm{~min}$; NS, not significant.
\end{abstract}

\begin{tabular}{lrrrr}
\hline \hline \multicolumn{1}{c}{ Solution } & \multicolumn{4}{c}{ Percentage of bacteria remaining } \\
\cline { 2 - 5 } & $\begin{array}{c}\text { No. of } \\
\text { experiments, } n\end{array}$ & \multicolumn{1}{c}{$0 \mathrm{~min}$} & $15 \mathrm{~min}$ & $30 \mathrm{~min}$ \\
\hline Water & 21 & $8 \pm 4$ & $14 \pm 3(<0 \cdot 05)$ & $14 \pm 3(<0 \cdot 05)$ \\
$\mathrm{FeCl}_{3}\left(10^{-5} \mathrm{M}\right)$ & 6 & $11 \pm 4$ & $19 \pm 9(\mathrm{NS})$ & $21 \pm 7(\mathrm{NS})$ \\
$\mathrm{CaCl}_{2}\left(10^{-4} \mathrm{M}\right)$ & 4 & $6 \pm 3$ & $26 \pm 8(\mathrm{NS})$ & $30 \pm 6(<0 \cdot 05)$ \\
$\mathrm{MgSO}_{4}\left(10^{-4} \mathrm{M}\right)$ & 3 & $6 \pm 3$ & $48 \pm 6(<0 \cdot 05)$ & $51 \pm 14(\mathrm{NS})$ \\
$\mathrm{Na}_{2} \mathrm{HPO}_{4}\left(10^{-4} \mathrm{M}\right)$ & 11 & $8 \pm 3$ & $20 \pm 6(<0 \cdot 01)$ & $26 \pm 8(<0 \cdot 01)$ \\
$\mathrm{CaCl}_{2}\left(10^{-4} \mathrm{M}\right)+\mathrm{Na}_{2} \mathrm{HPO}_{4}\left(10^{-4} \mathrm{M}\right)$ & 4 & $14 \pm 5$ & $91 \pm 6(<0 \cdot 001)$ & $96 \pm 6(<0 \cdot 001)$ \\
$\mathrm{MgSO}_{4}\left(10^{-4} \mathrm{M}\right)+\mathrm{Na}_{2} \mathrm{HPO}_{4}\left(10^{-4} \mathrm{M}\right)$ & 4 & $12 \pm 6$ & $96 \pm 11(<0 \cdot 001)$ & $102 \pm 5(<0 \cdot 001)$ \\
\hline \hline
\end{tabular}


(a)
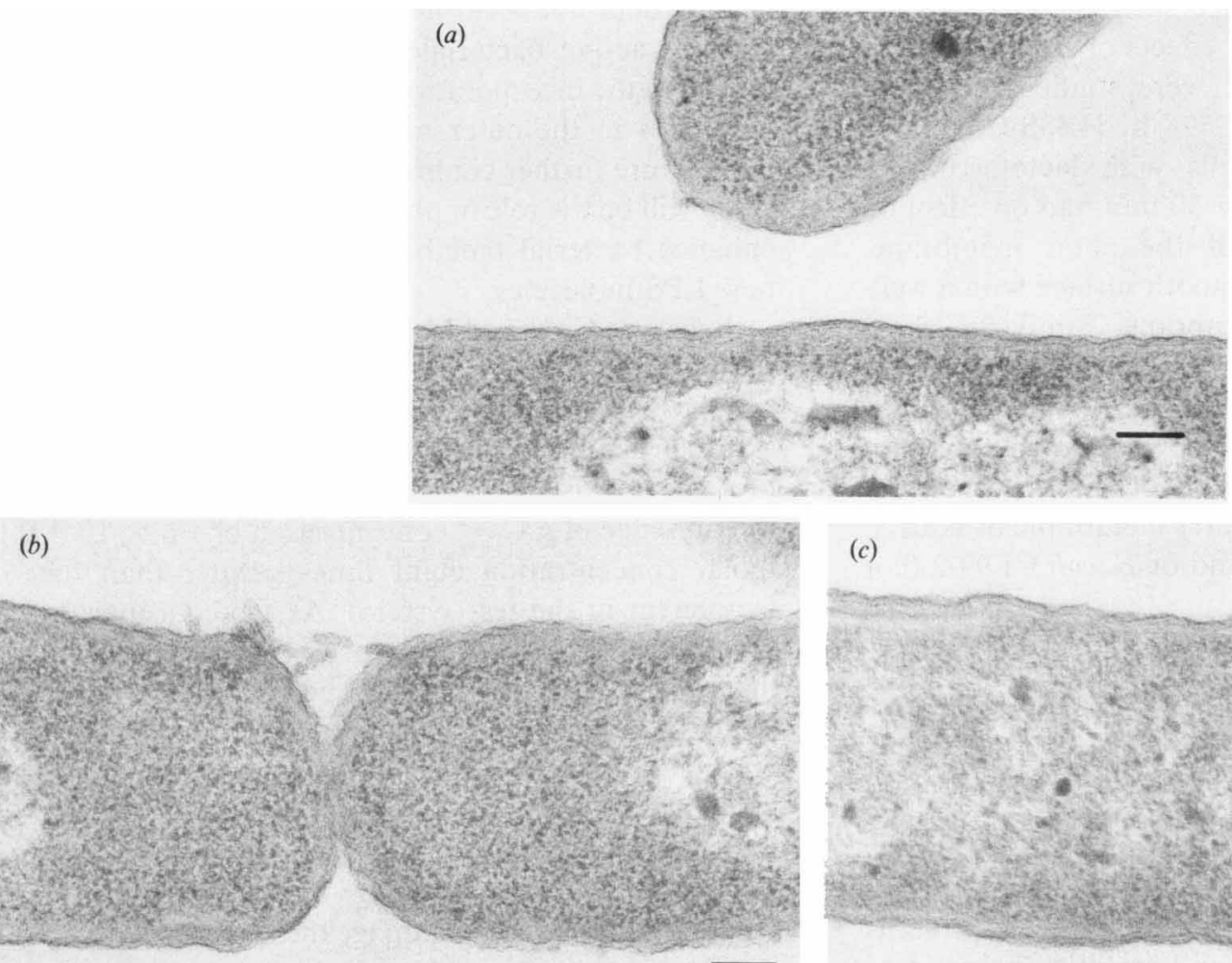

(c)
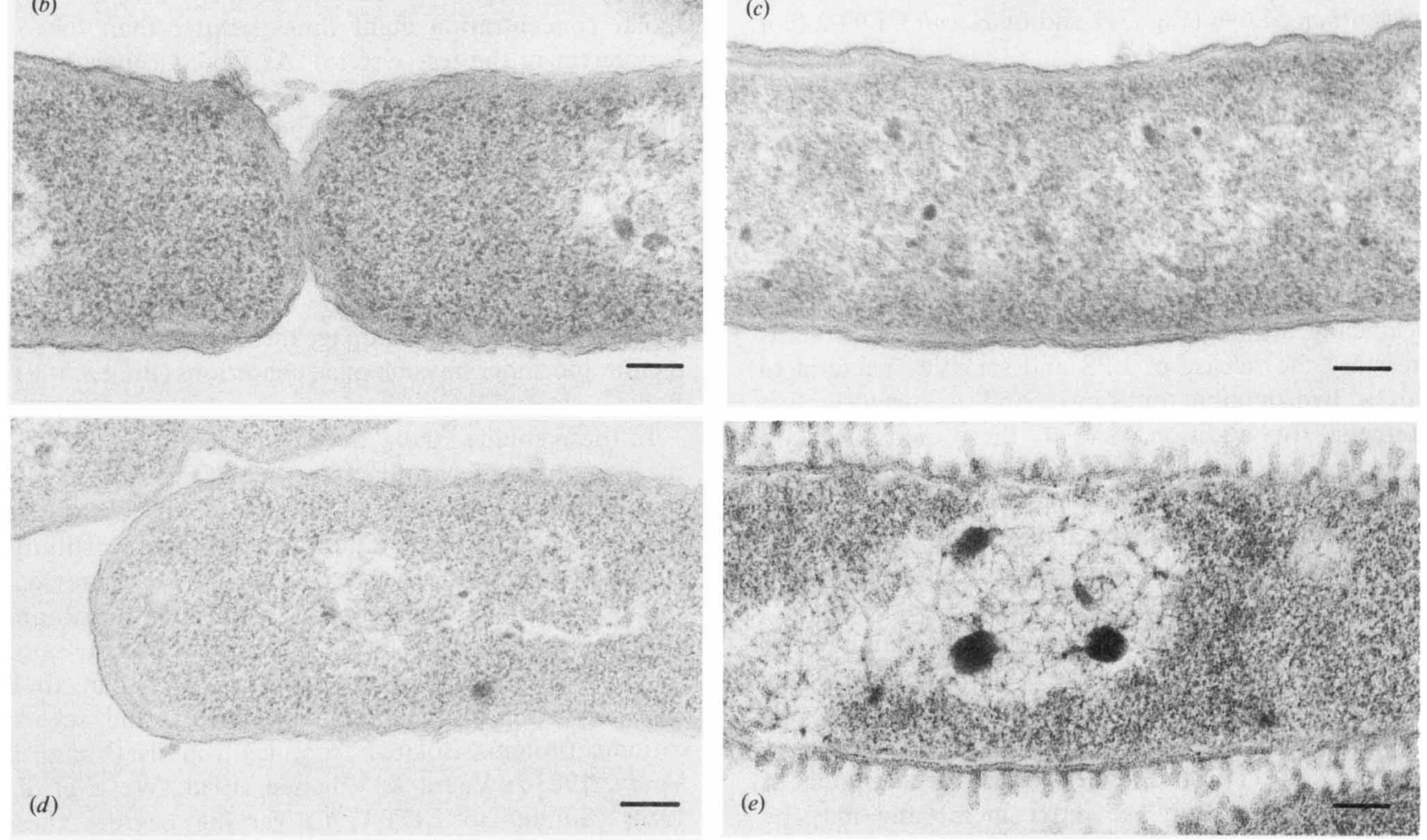

Fig. 3. Transmission electron micrographs showing the outer membrane of $S$. typhimurium SL696. (a) Incubated for 30 min in HBSS$\mathrm{CM} ;(b)$ incubated for $30 \mathrm{~min}$ in HBSS-CM containing EDTA $\left(10^{-5} \mathbf{M}\right) ;(c)$ incubated for $30 \mathrm{~min}$ in HBSS-CM containing transferrin $\left(2 \mathrm{mg} \mathrm{ml}^{-1}\right) ;(d)$ incubated for $30 \mathrm{~min}$ in HBSS-CM containing lactoferrin $\left(2 \mathrm{mg} \mathrm{ml}^{-1}\right)$; and $(e)$ incubated for $30 \mathrm{~min}$ in HBSS-CM containing polymyxin B $\left(30 \mu \mathrm{g} \mathrm{ml}^{-1}\right)$. In $(a)-(d)$ the outer bacterial membrane is relatively uniform without significant surface irregularities. In (e), numerous microvillus-like projections of the bacterial outer membrane are evident. Bars, $100 \mathrm{~nm}$.

Transferrin-exposed E. coli could gradually recover when held in $0.9 \%$ saline alone at $37^{\circ} \mathrm{C}$ with the percentage of viable bacteria remaining increasing from $12 \pm 5 \%$ immediately after dilution to $51 \pm 3 \%$ after 15 min incubation (mean \pm SEM of three experiments). In contrast, recovery was not observed with cells held in saline at $4{ }^{\circ} \mathrm{C}$ : the percentages of bacteria remaining were $12 \pm 5 \%$ immediately after dilution and only $10 \pm$ $1 \%$ after $15 \min (P<0.01$ compared to the studies at $37^{\circ} \mathrm{C}$ ). These findings were again consistent with the observations made with EDTA, and also suggest that repair of transferrin-induced membrane alteration requires active bacterial metabolism.

Transmission electron microscopy (TEM) of outer
membranes

Although EDTA has not been shown to induce membrane alterations detectable by TEM, membrane-active 
polycationic agents can produce such effects (Vaara \& Vaara, 1983a). Therefore, the effects of lactoferrin and transferrin on the membrane were studied by TEM. Incubating $S$. typhimurium SL696 in HBSS-CM alone (Fig. $3 a$ ) or treating the cells with lactoferrin $(b)$, transferrin $(c)$ or EDTA $(d)$ for 30 min had no effect on the ultrastructural features of the outer membrane. Bacteria showed a relatively smooth surface with a welldefined trilaminar outer membrane. Similarly, these agents had no significant ultrastructural effects on the outer membrane of $E$. coli CL99-2 (not shown). In contrast, incubation for $30 \mathrm{~min}$ with polymyxin B in HBSS-CM resulted in formation of numerous microvillus-like projections on the outer membrane of both $S$. typhimurium SL696 (Fig. 3e) and of E. coli CL99-2 (not shown).

\section{Discussion}

The results presented show that lactoferrin and transferrin alter the outer membrane of Gram-negative bacteria. Specifically, although differing in activity, these proteins can cause the release of LPS and sensitize bacteria to both a hydrophobic antibiotic and a surface-active detergent. In addition, all of these activities are modulated by $\mathrm{Ca}^{2+}$ and $\mathrm{Mg}^{2+}$. These findings are consistent with the studies of C. A. Bortner and co-workers who found that bactericidal effect of lactoferrin against Legionella pneumophila is inhibited by the addition of exogenous $\mathrm{Mg}^{2+}$ (Bortner et al., 1986).

The amount of LPS that can be released from the outer membrane varies between strains and is influenced by the $\mathrm{Ca}^{2+}$ concentration in the growth media. Leive (1974) and other investigators noted similar findings in studies with EDTA, and suggested that the alignment of LPS molecules within the outer membrane may be variable and partially dependent upon the availability of cations at the time of membrane formation. This has led to the hypothesis that for a given bacterial strain, if the outer membrane is assembled in the presence of high concentrations of cations, then increased numbers of cations are incorporated into the membrane and used to stabilize the anionic charge of the LPS core (Leive, 1974). This could then make the membrane more susceptible to factors that alter the cation-LPS relationship such as a chelator. By extension, inter-isolate variation in the incorporation of cations into the outer membrane could contribute to the observed differences between strains in the susceptibility to the chelators.

The ability of bacteria to recover from transferrinmediated sensitization to deoxycholate indicates that healing of the membrane damage can occur. That healing does not occur at $4{ }^{\circ} \mathrm{C}$ suggests that the process requires active bacterial metabolism. Healing may be related to the incorporation and stabilization of new LPS molecules in the outer membrane, but this hypothesis will require further confirmation. Also requiring further study will be the role of phosphate in this process: it may enhance bacterial metabolism or be incorporated into new LPS molecules.

Since free $\mathrm{Ca}^{2+}$ and $\mathrm{Mg}^{2+}$ are present in essentially all secretions, definition of the cation concentrations at which the membrane effects of lactoferrin and transferrin occur is important. These studies indicate that these proteins are able to induce at least partial LPS release in the presence of a $\mathrm{Ca}^{2+}$ concentration of $1.6 \times 10^{-4} \mathrm{M} \mathrm{(a}$ molar concentration eight times greater than that of lactoferrin in the test system). As the concentration of both the iron-binding proteins and $\mathrm{Ca}^{2+}$ and $\mathrm{Mg}^{2+}$ are heterogeneous in vivo, in selected micro-environments ionic conditions may exist where these membrane-active effects of lactoferrin and transferrin can occur. Elegant studies by $\mathrm{C}$. Pollack indicate that the $\mathrm{Ca}^{2+}$ concentration within the human macrophage phagolysosome is less than $10^{-4} \mathrm{M}$, suggesting one micro-environment where lactoferrin could damage the Gram-negative outer membrane under physiological conditions (Bullen, 1981; Pollack et al., 1986).

In these studies, there were consistent differences in the membrane effects of lactoferrin and transferrin, with lactoferrin causing greater LPS release, and transferrin having greater ability to induce deoxycholate sensitivity. Such heterogeneous observations are similar to previous studies with other agents that affect the outer membrane of Gram-negative bacteria. These agents include polylysine, protamine, the antimicrobial agents polymyxin B and polymyxin $B$ nonapeptide (PMBN), and several cationic proteins isolated from neutrophils (Vaara \& Vaara, 1983a; Vaara \& Viljanen, 1985; Weiss et al., 1984). Similar to EDTA, to varying degrees these polycationic compounds increase the permeability of the Gram-negative outer membrane to hydrophobic agents. The mechanism of action of the compounds appears to be at least partially due to an ability to insert into the bacterial outer membrane by binding to the anionic LPS molecules (Nikaido \& Vaara, 1985; Vaara \& Viljanen, 1985).

Lactoferrin and transferrin differ significantly in $\mathrm{pI}$ with transferrin anionic (pI $\sim 5.5$ ) and lactoferrin cationic (pI $\sim 8.5$ ) at neutral pH (Moguilevsky et al., 1985; White et al., 1978). This difference may contribute to the variation in their membrane effects. In being cationic, lactoferrin may share a mechanism of action with the polycationic agents as well as EDTA. Consistent with this hypothesis are the results of studies indicating that lactoferrin can be associated with the 
bacterial cell membrane (Arnold et al., 1977; Redhead et al., 1987).

This work serves to confirm the observation that the iron-binding proteins lactoferrin and transferrin damage the outer membrane of Gram-negative organisms. Such membrane effects could explain several previous observations on the antimicrobial activity of the proteins. Additionally, previous studies with EDTA and the polycationic agents suggest that both of these classes of membrane-permeabilizing compounds sensitize Gramnegative organisms to the effects of lysozyme and complement (Bryan, 1974; Hancock \& Wong, 1984; Joiner, 1985; Vaara \& Vaara 1983b; Vaara et al., 1984). It is reasonable to speculate that in altering the Gramnegative outer membrane, lactoferrin and transferrin may also sensitize bacteria to these other host antibacterial systems and thereby amplify their effects.

This work was supported by the Veterans Administration Research Service. The authors wish to thank Dr Allen Alfrey for measuring metal concentrations, Dr Keith Joiner for providing bacterial strains and $\mathrm{Dr}$ Martin Blaser for advice and critical review of the manuscript.

\section{References}

ARnold, R. R., Cole, M. F. \& MCGheE, J. R. (1977). A bactericidal role for human lactoferrin. Science 197, 263-265.

Arnold, R. R., Russell, J. E., Champion, W. J., Brewer, M. \& GAUTHIER, J. J. (1982). Bactericidal activity of human lactoferrin: differentiation from the stasis of iron deprivation. Infection and Immunity 35, 792-797.

Boesman-Finkelstein, M. \& Finkelstein, R. A. (1985). Antimicrobial effects of human milk. FEMS Microbiology Letters 27, 167-174.

BorTner, C. A., Miller, R. D. \& ARNold, R. R. (1986). Bactericidal effect of lactoferrin on Legionella pneumophila. Infection and Immunity 51, 373-377.

BRYAN, C. S. (1974). Sensitization of $E$. coli to the serum bactericidal system and to lysozyme by ethyleneglycoltetraacetic acid. Proceedings of the Society of Experimental Biology and Medicine 145, 14311433.

Bullen, J. J. (1981). The significance of iron in infection. Reviews of Infectious Diseases 3, 1127-1138.

Bullen, J. J., Rogers, H. J. \& Griffiths, E. (1978). Role of iron in bacterial infection. Current Topics in Microbiology and Immunology 80, $1-35$.

Coughlin, R. T., Tonsager, S. \& McGroaty, E. J. (1983), Quantitation of metal cations bound to membranes and extracted lipopolysaccharide of Escherichia coli. Biochemistry 22, 2002-2007.

Ellison, R. T., III, GIEHL, T. J. \& LAFORCE, F. M. (1988). Damage of the outer membrane of enteric Gram-negative bacteria by lactoferrin and transferrin. Infection and Immunity 56, 2774-2781.

Finkelstein, R. A., Sciortino, C. V. \& McIntosh, M. A. (1983). Role of iron in microbe-host interactions. Reviews of Infectious Diseases $\mathbf{5}$, S759-S777.

FitzGerald, S. P. \& Rogers, H. J. (1980). Bacteriostatic effect of serum: role of antibody to lipopolysaccharide. Infection and Immunity 27, 302-308.

Goldman, R. C. \& Leive, L. (1980). Heterogeneity of antigenic-sidechain length in lipopolysaccharide from Escherichia coli $\mathrm{O} 111$ and Salmonella typhimurium LT2. European Journal of Biochemistry 107, 145-153.

GRIFFITHS, E. (1975). Effect of $\mathrm{pH}$ and haem compounds on the killing of Pasteurella septica by specific antiserum. Journal of General Microbiology 88, 345-354.
Hancock, R. E. W. \& Wong, P. G. W. (1984). Compounds which increase the permeability of the Pseudomonas aeruginosa outer membrane. Antimicrobial Agents and Chemotherapy 26, 48-52.

Hukari, R., Helander, I. M. \& VaARA, M. (1986). Chain length heterogeneity of lipopolysaccharide released from Salmonella typhimurium by ethylenediaminetetraacetic acid or polycations. European Journal of Biochemistry 154, 673-676.

JOINER, K. A. (1985). Studies on the mechanism of bacterial resistance to complement-mediated killing and on the mechanism of bactericidal antibody. Current Topics in Microbiology and Immunology 121, 99-133.

Joiner, K. A., Goldman, R., Schmetz, M., Berger, M., Hammer, C. H., FranK, M. M. \& Leive, L. (1984). A quantitative analysis of $\mathrm{C} 3$ binding to $\mathrm{O}$-antigen capsule lipopolysaccharide and outer membrane protein of E. coli O111 B4. Journal of Immunology 132, 369-375.

Joiner, K. A., Grossman, N., Schmetz, M. \& Leive, L. (1986). C3 binds preferentially to long-chain lipopolysaccharide during alternative pathway activation by Salmonella montevideo. Journal of Immunology 136, 710-715.

Kalmar, J. R. \& ARnOLD, R. R. (1988). Killing of Actinobacillus actinomycetemcomitans by human lactoferrin. Infection and Immunity 56, 2552-2557.

LAFORCE, F. M. \& BOOSE, D. S. (1981). Sublethal damage of Escherichia coli by lung lavage. American Review of Respiratory Disease 124, 733737.

LEIVE, L. (1974). The barrier function of the Gram-negative envelope. Annals of the New York Academy of Sciences 235, 109-127.

Masson, P. L., Heremans, J. F. \& Dive, C. (1966). An iron-binding protein common to many external secretions. Clinica Chimica Acta 13, 735-739.

Masson, P. L., Heremans, J. F. \& Schonne, E. (1969). Lactoferrin an iron-binding protein in neutrophilic leukocytes. Journal of Experimental Medicine 130, 643-658.

Moguilevsky, N., Retegui, L. A. \& Masson, P. L. (1985). Comparison of human lactoferrins from milk and neutrophilic leucocytes. Biochemical Journal 229, 353-359.

Mokrasch, L. C. \& MCGilvery, R. W. (1956). Purification and properties of fructose-1,6-diphosphatase. Journal of Biological Chemistry 221, 909-927.

NiKaIDO, H. \& VAaRA, M. (1985). Molecular basis of bacterial outer membrane permeability. Microbiological Reviews 49, 1-32.

Norrod, P. \& Williams, R. P. (1978). Effects of iron and culture filtrates on killing of Neisseria gonorrhoeae by normal human serum. Infection and Immunity 21, 918-924.

Pollack, C., Straley, S. C. \& Klempner, M. S. (1986). Probing of the phagolysosomal environment of human macrophages with a $\mathrm{Ca}^{2+}$. responsive operon fusion in Yersinia pestis. Nature, London 322, 834 836.

RAINARD, P. (1986). Bacteriostasis of Escherichia coli by bovine lactoferrin transferrin and immunoglobulins (IgG1, IgG2, IgM) acting alone or in combination. Veterinary Microbiology 11, 103-115.

RedheAD, K., Hill, T. \& CharT, H. (1987). Interaction of lactoferrin and transferrins with the outer membrane of Bordetella pertussis. Journal of General Microbiology 133, 891-898.

Spik, G., Cheron, A., Montreuil, J. \& Dolby, J. M. (1976). Bacteriostasis of a milk-sensitive strain of Escherichia coli by immunoglobulins and iron-binding proteins in association. Infection and Immunity 14, 911-918.

Stephens, S., Dolby, J. M., Montreuil, J. \& Spik, G. (1980). Differences in inhibition of the growth of commensal and enteropathogenic strains of Escherichia coli by lactotransferrin and secretory immunoglobulin A isolated from human milk. Immunology 41, 597-603.

VAARA, M. \& VAARA, T. (1983a). Polycations as outer membranedisorganizing agents. Antimicrobial Agents and Chemotherapy 24, 114-122.

VAARA, M. \& VAARA, T. $(1983 b)$. Sensitization of Gram-negative bacteria to antibiotics and complement by a non-toxic oligopeptide. Nature, London 303, 526-528. 
VaARA, M. \& VilJanen, P. (1985). Binding of polymyxin B nonapeptide to Gram-negative bacteria. Antimicrobial Agents and Chemotherapy 27, 548-554.

VaARa, M., Viljanen, P., VaARa, T. \& Makela, P. H. (1984). An outer membrane-disorganizing peptide PMBN sensitizes $E$. coli strains to serum bactericidal action. Journal of Immunology 132, 2582-2589.
Weiss, J., Muello, K., Victor, M. \& Elsbach, P. (1984). The role of lipopolysaccharides in the action of the bactericidal/permeability increasing neutrophil protein on the bacterial envelope. Journal of Immunology 132, 3109-3115.

White, A., HANDleR, P., Smith, E. L., Hill, R. L. \& Lehman, I. R. (eds) (1978). Principles of Biochemistry, 6th edn, p. 906. New York: McGraw Hill. 